\title{
Migrant Workers' Willingness to Purchase Houses on the Working Sites and Its Influencing Factors-Take Guangzhou as an Example
}

\author{
Jie Li \\ School of Public Administration and Emergency Management, Jinan University, Guangzhou, China \\ Email: LIJIEEE201314@163.com
}

How to cite this paper: Li, J. (2018) Migrant Workers' Willingness to Purchase Houses on the Working Sites and Its Influencing Factors-Take Guangzhou as an Example. Open Journal of Social Sciences, 6, 8-28.

https://doi.org/10.4236/jss.2018.67002

Received: June 6, 2018

Accepted: July 10, 2018

Published: July 13, 2018

Copyright $\odot 2018$ by author and Scientific Research Publishing Inc. This work is licensed under the Creative Commons Attribution International License (CC BY 4.0).

http://creativecommons.org/licenses/by/4.0/

\begin{abstract}
With the development of urbanization in China, more and more migrant workers are working in cities, gradually becoming an important part of urban construction and social development. Guangzhou is one of the major influxes of migrant workers. Migrant workers want to integrate better into urban life. Housing is an important condition. In order to regulate the purchase of real estate and migrant workers, this paper studies the willingness of peasant workers in Guangzhou to purchase houses and the influencing factors. This paper mainly uses the survey method to collect the collected data using SPSS17.00 for statistical analysis of the sample, interactive analysis of the contingency table, and two-factor correlation analysis, to obtain the willingness of the migrant workers to purchase houses at the working sites and its influencing factors. Mainly from four aspects to analyze the migrant workers in the workers' purchase intention and its influencing factors: Self-characteristics, family characteristics, employment characteristics and working sites characteristics. The results show that the older migrant workers are, the weaker willingness to purchase houses, the higher migrant workers' level of education, the higher income level, and the higher job satisfaction, the stronger willingness to purchase houses. The higher ratio of migrant workers' non-labour population is, the weaker willingness to purchase houses. The migrant workers who have contracted land in their hometowns are more reluctant to buy houses at the working sites. Migrant workers have friends and relatives in the working area. The more satisfied they are with the cultural environment and convenience of transportation, the stronger willingness to purchase a house. This article points out that migrant workers should be provided with guidance in the purchase of houses on the working site, improve the ability of migrant workers to purchase houses, increase the construction of affordable housing, solidify rural rights and interests, encourage migrant workers to "carry capital
\end{abstract}


into the city", improve the vocational training system, and strengthen migrant workers. Employment ability allows more migrant workers to have the ability to purchase homes on the working site and increase their willingness to purchase, thereby increasing their sense of well-being.

\section{Keywords}

Migrant Workers, Working Sites, Willingness to Purchase Houses, Influencing Factors, Guangzhou City

\section{Introduction}

\subsection{Research Background}

With the development of China's urbanization process, more and more migrant workers are working in cities, gradually becoming an important part of urban construction and social development. With the large influx of the population, the contradiction between the migrant workers living in the corresponding working cities has become more and more prominent and has drawn the attention of the government and society.

The economic development of Guangzhou is one of the major inflow areas for migrant workers. Due to the influence of traditional hierarchical concepts, some urban residents in Guangzhou like to characterize migrant workers as "outsiders" and there is a clear sense of superiority. Therefore, migrant workers' groups have always been in a state of lack of rights in the city. The policies for the purchase of houses for non-resident households in Guangzhou are as follows: non-resident households of this city shall purchase one set, and shall provide a personal income tax payment certificate or social insurance payment certificate in this city for five consecutive years before the purchase of the house; Residents in Conghua, Zengcheng limit purchase (including gifts) a set. The policy of restricting purchases in Guangzhou is a high threshold for the purchase of migrants, which greatly reduces the willingness of migrant workers to purchase houses.

At the end of 2017, the resident population of Guangzhou was 14.4984 million, a net increase of 455,000 from the previous year. In fact, in the past three years, the permanent population growth in Guangzhou has maintained a relatively rapid increase, reaching 42.06 million people, 542,400 people and 454,900 people respectively. The household registration population was 8.9978 million, a net increase of 273,800. Among them, 180.06 million households migrated, 47,100 moved out, and machinery increased by 135,500 . Compared with the 2016 migration of 118.7 thousand households and mechanical growth of 72,500 people, in 2017 the number of immigrant households in Guangzhou increased by approximately $50 \%$, and the mechanical growth population nearly doubled, which was the highest level in the past five years. According to the draft of the 
"Guangzhou Urban Master Plan (2017-2035)" previously disclosed by the anecdote, in 2035, the size of the resident population of the Guangzhou municipality was controlled at about 20 million people. This also means that in the next 18 years, the average annual increase in Guangzhou will be around 300,000.

However, many migrant workers want to integrate into urban life, then housing is a key condition. The settlement of urban living conditions for migrant workers will not only improve the quality of life of migrant workers and their development in cities, but will also benefit the coordinated development of China's social and economic relations. In the past literature, most of them are investigating and researching the willingness of peasant workers to stay in the city, and there is less research on the willingness of migrant workers to buy houses. This article selected Guangzhou as a research site. Because Guangzhou is relatively developed and migrant workers are relatively intensive, they investigated the willingness of migrant workers in Guangzhou to purchase houses and the influencing factors.

\subsection{The Living Conditions of Migrant Workers in Guangzhou}

In the past two decades, China's urban construction has grown by leaps and bounds. The living conditions of hundreds of millions of important builders-migrant workers-have not only been simultaneously improved, but have even worsened. Many migrant workers who have left their hometowns have been working in cities for a decade or two but have been excluded from the city's housing security and public welfare systems. They stayed in the city for a long time and remained indefinitely. "Unable to stay in the city and return to the countryside" This is the voice of most migrant workers. It is also a typical problem left behind by the rapid development of urban construction. The problems faced by migrant workers are not a simple issue. They not only reflect the drawbacks of the urbanization process, such as the defects of the household registration system in the dual urban-rural system, the imperfection of the economic system, regional discrimination, employment income, and social security. Issues such as citizenization, training and education.

Due to the impact of the soft landing of the domestic economy and the slowdown in GDP growth, coupled with the regulation of Guangzhou's housing prices, the income of migrant workers in Guangzhou has significantly decreased. According to the statistics of 2016, the population living in towns and cities is 767.50 million, accounting for $55.88 \%$; the population living in the countryside is 60.599 million, accounting for $44.12 \%$. The rural population has obvious signs of urbanization and migration. Most of the migrant workers have been aging, and new generations of young people are reluctant to "carry out their father's business". As a result, migrant workers have experienced shortages in many places.

In addition, the high level of urban consumption, for most migrant workers, can not afford it. Although the migrant workers in Guangzhou often cover 
houses worth hundreds of millions, they cannot afford to build a shelter. Coupled with employment difficulties, settled difficulties, children's schooling and other factors, it is difficult for migrant workers to purchase a house in the work place, only to choose the form of renting, self-built housing, etc. In general, the living form of migrant workers is mainly divided into three types: First, the collective dormitories built by industrial parks or factories; second, the service industry employers rent peasant or commercial houses, and place bunk beds instead of employee dormitories; thirdly, migrant workers find their own home in the village.

\section{Research Review}

\subsection{Study on the Status of Migrant Workers' Housing}

When studying the willingness of migrant workers to purchase houses and their influencing factors, it is necessary to understand the migrant workers' living conditions. Because the housing conditions of migrant workers will affect their willingness to purchase a house, the definition of the housing scoring standard plays a major role in this article. In recent years, the status quo of rural migrant workers' housing has become a hot spot for people's livelihood, and it has been deeply concerned by all sectors of the society. Therefore, there are many related research results.

Liang Yanping summed up the migrant workers' housing conditions mainly in three points: The migrant workers in the cities have small per capita housing; the housing facilities are relatively simple; the complex housing conditions lack safety protection [1]. Song Ru's analysis of the housing status of migrant workers in Ningguo City in Anhui Province shows that there are three types of housing for migrant workers: unit dormitories, renting houses, and work sheds. These three accommodation methods all have a small living area and poor environment [2]. Wang Run obtained an analysis of the status of migrant workers' houses in Nanyang City, Henan Province. The main mode of migrant workers in Nanyang City is renting a village in the city, factory dormitories, and their own houses; the size of the housing is relatively small and the unit type is relatively simple; the housing situation is poor., The supporting facilities are small; the expenditure on housing is low [3]. Gao Bo et al. in the analysis of the status quo of rural migrant workers, migrant workers living in the status quo is mainly based on rental housing, life cycle variables, the nature of employment and education represented by the market capacity, etc. have a significant impact on migrant workers' housing choices [4]. Liao Jinlu summed up the characteristics of the migrant workers' urban housing status: relatively poor living conditions; poor living quality; a low proportion of self-owned housing; and small household per capita living area [5]. Liang $\mathrm{Yu}$ and others analyzed the housing status of rural migrant workers in Liaoning Province and found that the number of rural migrant workers is large, and the proportion of urban-owned housing is small; migrant workers are difficult to purchase in cities; and the quality of ur- 
ban living is low [6].

\subsection{Research on Migrant Workers' Housing Needs}

Defining the demand of migrant workers for housing is conducive to establishing a practical starting point for this study. Migrant workers' houses are mainly composed of two parts: Leasing and purchasing their own.

According to Guo Xinyu et al.'s survey data of 406 migrant workers' families in Fengning County, Hebei Province, the rental demand of migrant workers is sensitive to the current income, and the demand for home purchases is sensitive to permanent income. Rental consumption is highly sensitive to price changes [7]. Tian Hongyan and others conducted policy responses in the form of questionnaires and in-depth interviews to investigate the status and needs of migrant workers in Chongqing: to remove family register benefits, advance the reform of household registration system, and improve the housing security system and implement [8]. Hu Yuanrui and others based on data from migrant workers surveyed in Chenghua District of Chengdu found that the characteristics of housing needs of peasant workers in Chenghua District are: higher quality housing needs; more frequent work shifts, greater housing demand fluctuations, weak savings awareness, and better traffic location Work location [9]. Tang Rentian summed up the policy response to the housing demand of migrant workers in Zhengzhou: improve the existing housing policy system; improve the self-protection ability of migrant workers; and improve the supporting measures [10].

\subsection{Research on Influence of Peasant Workers' Purchase Behavior}

Zhu Zhongkun and others used the Logit model to carry out empirical analysis and concluded that the higher the income level, the higher the level of education, and the higher the professional skills required for work, the greater willingness of migrant workers to purchase houses [11]. Liang Zhimin and others used data from more than 900 farmer households in Jiangxi Province to use the Logit model to analyze the influencing factors of the willingness of the rural labor force to purchase homes on the construction site, and concluded that personal characteristics, social capital, environmental characteristics, and family characteristics are the main influencing factors in the willingness to purchase a house. [12]. Li Ying took 377 migrant workers in Fujian Province as the survey object and summed up the suggestions for raising the willingness of migrant workers to purchase houses in cities: cost reduction; strong protection; and raising the income level of migrant workers [13]. Wang Yanzhi found that personal characteristics, characteristics of family characteristics, and job satisfaction of migrant workers are the main factors affecting the willingness of migrant workers to purchase houses [14]. Cheng Yin et al. used a total of 357 questionnaires from Beijing, Wuhan, and Tianjin, and used a binary regression model to analyze the status of marital status, number of workers hitting the house, number of family 
members, satisfaction with living conditions, working conditions, and house price expectations. Factors such as this affect the willingness of migrant workers to purchase houses in cities [15]. Zhang Xinmin to Dagang Town, Panyu District, Guangzhou, for example, the use of Eviews software for the regression analysis of the questionnaire data, to get the rent, cost of living, housing satisfaction, the number of occupants is a significant factor affecting migrant workers in the work site purchase plan [16].

\subsection{Existing Research Review}

In summary, well-known scholars have achieved certain results in the related research fields of migrant farmer housing. There are also many documents on the willingness of migrant workers to purchase houses and their influencing factors in the construction sites, which greatly inspired this study. The study perspectives, research ideas and methods, and model construction analysis of the above-mentioned documents help me to determine the entry point of this article, the selection of research methods, and statistical analysis methods. Except for the above, some of the factors influencing the willingness of migrant workers to purchase their homes in the above-mentioned literature also provide good ideas and suggestions for the study, which are helpful for the selection of research variables, the design of survey questionnaires, and the optimization of the survey questionnaire structure. Scientific and reasonable questionnaires to improve the value of this study.

\section{Empirical Analysis}

Migrant workers are also called peasant workers. They are unique to China and actually refer to workers who are engaged in non-agricultural work in the city and whose accounts are agricultural accounts. Their main features include: The account held is an agricultural account. From the countryside; engaged in non-agricultural work; being employed or self-employed. As of the end of 2017, the total number of migrant workers throughout the country was 282.52 million, an increase of $1.7 \%$ over the previous year. Among them, 171.85 million were migrant workers, an increase of $1.5 \%$; and 11.467 million were local migrant workers, an increase of $2.0 \%$. The research object of this article is the migrant workers in Guangzhou City.

The sample data used in this study is mainly based on the questionnaire survey on the willingness and influencing factors of the migrant workers' willingness to purchase property at the construction sites conducted two months before and after the Spring Festival in 2018, that is, from the beginning of January to the beginning of March. The scope of this survey is for road construction or housing construction areas where there are many migrant workers in Cen Village, Tianhe District, Guangzhou, Dashi and Shiqiao Village, Panyu District, and Huangpu District. After conducting face-to-face interviews with migrant workers, a total of 300 questionnaires were completed. After invalid samples were 
removed, 282 valid questionnaires were finally obtained and the effective sample size was $94 \%$. This study mainly analyzes the willingness of migrant workers to purchase houses in the working sites and its influencing factors from four aspects, which are their own characteristics, family characteristics, employment characteristics and working area characteristics.

\subsection{Sample Descriptive Statistical Analysis}

In order to understand the situation of the surveyed subjects more clearly and intuitively, SPSS 17.0 was used to analyze the statistical characteristics of the four parts of the questionnaire, namely, the characteristics of the migrant workers themselves, family characteristics, employment characteristics, and working site characteristics. The variables were assigned and used. Frequency analysis and statistical methods, the analysis results are summarized in Table 1.

1) The overall purchase intention

It can be observed from Table 1 that the percentage of migrant workers who are unwilling to purchase a house is $81.8 \%$, and the overall willingness of migrant workers to purchase a house in a working place, namely Guangzhou, is unwilling.

\section{2) Own characteristics}

From Table 1, it can be observed that, in terms of gender, more males than females can see the gender structure of migrant workers: more females stay in rural areas, males go out to work more, and husbands and wives go out to work together. This survey result is in line with the reality, because most of the migrant workers who work outside do physical work, and women do not have advantages in this respect. In terms of marital status, most of the respondents have already married, and $70 \%$ of the married respondents have already married. In terms of age, most of the respondents were middle-aged. This is also in line with the reality, because most of the migrant workers are engaged in physical labor, and young and strong are mostly. In terms of education level, respondents have a relatively low level of education, accounting for $41.8 \%$ of primary schools and below, and $36.4 \%$ of junior high schools, which is in line with the low level of migrant workers. In terms of personality, the respondents were more conservative in terms of personality, accounting for $47.3 \%$, which is in line with the more conservative and traditional status of migrant workers. In terms of health status, most of the respondents' health status was normal, reaching $70 \%$.

\section{3) Family characteristics}

It can be observed from Table 1 that in the non-labor population ratio of the family, the non-labor population ratio of the respondents is higher than 0.5, which is in line with the fact that the migrant workers have stronger fertility desires and more children. The larger the ratio of household to non-labor population is, that is, the heavier the household burden is, the greater the pressure on home buyers. Whether or not there is a contracted land in the hometown, the respondent has a large number of people who own the contracted land in their 
Table 1. Sample statistics analysis table.

\begin{tabular}{|c|c|c|c|c|}
\hline Chara & acteristic variables & Types & Frequency & Percentage \\
\hline Own characteristics & Willingness to buy a house & Unwilling & 231 & 81.8 \\
\hline & & Willing (or purchased) & 51 & 18.2 \\
\hline & Gender & Male & 215 & 76.4 \\
\hline & & Female & 67 & 23.6 \\
\hline & Marital Status & Married & 200 & 70.9 \\
\hline & & Unmarried & 82 & 29.1 \\
\hline & Age & $20-30$ & 41 & 14.5 \\
\hline & & $31-45$ & 164 & 58.2 \\
\hline & & $46-60$ & 77 & 27.3 \\
\hline & Education level & Primary school and below & 118 & 41.8 \\
\hline & & Junior high school & 103 & 36.4 \\
\hline & & High School (secondary school) & 51 & 18.2 \\
\hline & & College & 10 & 3.6 \\
\hline & Character & Adventure & 46 & 16.4 \\
\hline & & Intermediate & 103 & 36.4 \\
\hline & & Conservative & 133 & 47.3 \\
\hline & Health status & Very bad & 56 & 20 \\
\hline & & General & 200 & 70.9 \\
\hline & & Better & 26 & 9.1 \\
\hline Family characteristics & Family non-labor force ratio & $<0.5$ & 87 & 30.9 \\
\hline & & $0.5-1$ & 195 & 69.1 \\
\hline & Is there a contracted land in hometown? & No & 41 & 14.5 \\
\hline & & Yes & 241 & 85.5 \\
\hline Employment characteristics & Workers' monthly income & 2000 yuan or less & 107 & 38.2 \\
\hline & & $2001-4000$ yuan & 149 & 52.7 \\
\hline & & 4001 yuan or more & 26 & 9.1 \\
\hline & Employment patterns & Employer/owner & 16 & 5.5 \\
\hline & & Self-employed & 0 & 0 \\
\hline & & Wage employment & 266 & 94.5 \\
\hline & Industry type & Labor-intensive & 282 & 100 \\
\hline & & Capital intensive & 0 & 0 \\
\hline & & Technology-intensive & 0 & 0 \\
\hline & Social security fee payment & no & 179 & 63.6 \\
\hline & & Paid but less than five years & 61 & 21.8 \\
\hline & & Paid and has been in five years & 42 & 14.5 \\
\hline & Current living conditions & Rental Private & 215 & 76.4 \\
\hline & & Leasing public rental or low-cost housing & 61 & 21.8 \\
\hline & & Shelter or work place accommodation & 6 & 1.8 \\
\hline & & Others & 0 & 0 \\
\hline
\end{tabular}




\begin{tabular}{|c|c|c|c|c|}
\hline & \multirow[t]{3}{*}{ Workplace satisfaction } & Not satisfied & 92 & 32.7 \\
\hline & & General & 159 & 56.4 \\
\hline & & Basically satisfied & 31 & 10.9 \\
\hline & \multirow[t]{3}{*}{ Working time satisfaction } & Not satisfied & 77 & 27.3 \\
\hline & & General & 169 & 60 \\
\hline & & Basically satisfied & 36 & 12.7 \\
\hline & \multirow[t]{3}{*}{ Labor protection satisfaction } & Not satisfied & 113 & 40 \\
\hline & & General & 59 & 56.4 \\
\hline & & Basically satisfied & 10 & 3.6 \\
\hline & \multirow[t]{3}{*}{ Technical training satisfaction } & Not satisfied & 123 & 43.6 \\
\hline & & General & 113 & 40 \\
\hline & & Basically satisfied & 46 & 16.4 \\
\hline \multirow[t]{8}{*}{ Worksite characteristics } & \multirow[t]{2}{*}{ Friends and relatives at worksite } & No & 56 & 20 \\
\hline & & Yes & 226 & 80 \\
\hline & \multirow[t]{3}{*}{ Cultural environment } & Poor & 97 & 34.5 \\
\hline & & General & 164 & 58.2 \\
\hline & & Better & 21 & 7.3 \\
\hline & \multirow[t]{3}{*}{ Convenient traffic } & Poor & 92 & 32.7 \\
\hline & & General & 169 & 60 \\
\hline & & Better & 21 & 7.3 \\
\hline
\end{tabular}

hometowns, and the contracted land can be used to gain returns. The migrant workers are not willing to give up the proceeds obtained from the contracted land, which reduces the willingness of the migrants to buy houses on the working site.

\section{4) Employment characteristics}

It can be observed from Table 1 that in terms of monthly income, the respondents' monthly income in the range of 2000 to 4000 yuan accounts for $90 \%$, and the wage level is relatively low. The pressure on home buyers in the city is relatively high. In terms of employment patterns, most of the respondents were wage-employed workers, accounting for $94.5 \%$, which is in line with the relatively low level of migrant workers' culture and the relative lack of funds. The pressure on buying houses in cities is relatively large. In terms of the nature of work, the nature of the work of respondents is labor-intensive, which is in line with the current status of migrant workers who are mostly engaged in physical labor. In terms of social security contributions, most of the respondents did not purchase social security or purchase social security for less than five years. Migrant workers must pay social security for five consecutive years in order to purchase a house in Guangzhou, so most of the respondents did not qualify for a home. In terms of living conditions, most of the respondents have rented private houses or public rental housing, which means that the purchase of houses in the 
construction sites is a greater pressure for migrant workers. In terms of job satisfaction, most of the interviewees are generally satisfied with the work, and the more satisfied they are with the work, the higher the willingness of the migrant worker to stay in the work site.

\section{5) Worksite characteristics}

It can be observed from Table 1 that most of the interviewees have relatives and friends in the working area in terms of whether they have friends or relatives in the working area, which is in line with the current situation in which the migrant workers are engaged in similar industries and they like to concentrate on one another. In terms of the cultural environment of the working area, most of the interviewees evaluated the cultural environment of the working area well. Culture is an important competitiveness of the city. The Guangzhou municipal government should accept the migrant workers from all corners of the country more comprehensively, and should treat the local people. The problem of migrant workers' integration into the city is answered and publicized, and various paths and methods are used to solve the migrant workers' urban living problems. In respect of the convenience of transportation at the construction site, most of the interviewees thought that the traffic at the working site was more convenient. The city of Guangzhou has developed transportation facilities, a wide range of subway lines and intensive transportation, and bus lines, express buses, etc., which make life travel flexible and convenient. At the same time, there are also transport facilities such as airports, high-speed rail stations, and railway stations, which provide a variety of transportation options for migrant workers in Guangzhou when returning home.

\subsection{Analysis on the Willingness of Migrant Workers' Purchase of Houses and Their Influencing Factors in the Working Site in Guangzhou City}

This article studies the willingness of migrant workers to purchase homes on the working site. It is a categorical variable. There are only two choices for the willingness to purchase a home, "unwillingness" and "willingness or purchase". There are two major categories of variables in the influencing factors., are the class variables and the ordinal variables.

For the correlation analysis of fixed-class variable and fixed-class variable, the method of interaction analysis of contingency table is adopted and the chi-square test is performed. For the analysis of fixed-class variable and sequence variable, the double analysis is used. Factor analysis, the correlation coefficient used is the Kendall correlation coefficient, and the significance test is a two-sided test.

1) The Influence of Self-characteristic Factors on Purchase Willingness

From Table 2, we can see that the willingness to buy a house and the gender of the Gamma $=-0.128<0.3$, indicating that there is a certain correlation between gender and the willingness to purchase, $\mathrm{Sig}=0.765>0.05$, so gender is not a significant factor affecting the willingness to buy a house. The willingness to purchase a house and the marital status of Gamma $=0.806>0.7$, indicating 
that the marital status is highly related to the willingness to purchase a home. Therefore, it can be assumed that when the marital status is unmarried, the possibility of purchasing a house in Guangzhou is greater; Sig $=0.002<0.05$, indicating the marital status It is a significant factor that affects the willingness to purchase a home. Unmarried migrant workers have a strong willingness to purchase houses, which is in line with the status quo that modern homes must be built first.

Table 3 shows that the significant factors that affect the willingness to purchase a house are age, education level, personality, and health status. The correlation coefficient for age is -0.628 . The age and purchase intention are moderately correlated, and age is negatively correlated with the willingness to purchase. The greater the willingness to purchase a house, the lower the degree of education; the correlation coefficient of the education level is 0.648 , the degree of education is moderately related to the willingness to purchase a house, and the degree of education is positively related to the willingness to purchase a house. The higher the degree of education is, the stronger the willingness to purchase a house is; the correlation coefficient of the personality is -0.299 . Personality is related to the low degree of willingness to buy a house. Personality is negatively correlated with the willingness to purchase a house. The more conservative the personality is, the lower the willingness to purchase a house is. The correlation

Table 2. Willingness to purchase-gender, marital status cross-tabulation.

\begin{tabular}{cccc}
\hline & & \multicolumn{2}{c}{ Willingness to Purchase (\%) } \\
\cline { 2 - 3 } Gender & Male & Unwilling & Willing (or purchased) \\
\hline \multirow{2}{*}{ Marital Status } & Female & 84.6 & 19 \\
& Married & 15.4 \\
& Unmarried & 92.3 & 7.7 \\
\multicolumn{2}{c}{ Gamma $=0.806, \mathrm{df}=1, \mathrm{Sig}=0.002$} & \\
\hline
\end{tabular}

Table 3. Kendall's correlation coefficient of willingness to buy a house, age, education, etc.

\begin{tabular}{lcc}
\hline & \multicolumn{1}{c}{ Kendall's correlation coefficient } \\
\hline & \multicolumn{1}{c}{ Willingness to Purchase } \\
\hline Age & $0.628^{* *}$ & Sig. (Bilateral) \\
Education level & $0.648^{* *}$ & 0 \\
character & $-0.299^{*}$ & 0.021 \\
Health status & $0.507^{* *}$ & 0 \\
${ }^{* *}$ Confidence (Bilateral) is 0.01, the correlation is significant. ${ }^{*}$ Confidence (Bilateral) is 0.05 , the correlation \\
is significant.
\end{tabular}


coefficient of health status is 0.507 . The health status is moderately related to the willingness to purchase a house, and the health status is positively related to the willingness to purchase a house. The healthier the body is, the higher the willingness to buy a house.

With the increase of age, the health status of migrant workers is gradually declining, and their ability to bear risks is getting lower and lower. At the same time, migrant workers will have the idea of deciduous roots, and the local complex will become more and more concentrated, so the older the buyers The lower the willingness. Higher-educated migrant workers generally receive higher wages, and their ability to purchase houses is higher than that of lower-level migrant workers. Therefore, the higher the education level, the greater the willingness to buy houses. The better the migrant workers' physical condition, the stronger their ability to bear risks, so the better the physical condition, the higher the willingness to buy houses.

2) The Influence of Family Characteristics on Their Willingness to Purchase Homes

From Table 4, we can see that Gamma $=-0.782$ for the ratio of household purchase intention to household non-labor population, indicating that the ratio of non-labor population in the family is highly correlated with the willingness to purchase houses. Therefore, it can be considered that if the ratio of non-labor force households is higher, the possibility of purchasing houses in Guangzhou may be higher. The smaller the sex, Sig $=0.003<0.05$, indicating that the ratio of non-labor population in the family is a significant factor influencing the willingness to purchase a house.

The higher the ratio of non-labor force in the family, the higher the non-labour population in the family, the heavier the burden on behalf of the family, and the greater pressure on home purchases, so the higher the ratio of the family workforce, the less willingness to buy houses.

From Table 4, we can see that the willingness to purchase a house and whether or not there is a contracted land in the home town of Gamma $=-1.00$ indicates whether or not there is a contracted land in the home town that is highly relevant to the willingness to purchase a house. This can be considered as the

Table 4. Willingness to purchase-non-labor population ratio in home and contracted land in hometown cross-tabulation.

\begin{tabular}{lccc}
\hline & & \multicolumn{2}{c}{ Willingness to Purchase (\%) } \\
\cline { 3 - 4 } Non-Labor Population Ratio in Home & $<0.5$ & 58.8 & 41.2 \\
& $0.5 \sim 1$ & 92.1 & 7.9 \\
Contracted Land in Hometown & Gamma $=$ & $-0.782, \mathrm{df}=1, \mathrm{Sig}=0.003$ \\
& No & 0 & 100 \\
& Yes & 95.7 & 4.3 \\
& \multicolumn{2}{c}{ Gamma $=-1.00, \mathrm{df}=1, \mathrm{Sig}=0.00$} \\
\hline
\end{tabular}


possibility of purchasing a house in Guangzhou when there is a contracted land in the hometown. The smaller the sex, Sig $=0.00$, indicating whether the contracted land in the hometown is a significant factor affecting the willingness to purchase a home.

Farmers who have household contracted land enjoy the right to use contracted land, income, and transfer of land contracted management rights according to law. Household contracted land is a very important part of farmers' property. Many farmers who work outside the home are not obliged to abandon such rights, so they have contractors in their hometowns. Migrant workers are less willing to purchase their houses.

3) The Influence of Employment Characteristics on Their Willingness to Purchase Homes

Table 5 shows that the significant factors affecting the willingness to purchase a house include monthly income, employment patterns, whether to pay social security fees, work place, working hours, labor protection, and technical training. The correlation coefficient of monthly labor income is 0.531 . It is moderately correlated with the willingness to purchase a house. The monthly income from work is positively correlated with the willingness to purchase a house. The higher the monthly income, the higher the willingness to purchase a house; the correlation coefficient of employment pattern is -0.51 . The employment pattern is moderately related to the willingness to purchase a house, and the employment pattern and purchase intention There is a negative correlation. The higher the employer's or employer's willingness to purchase a house is, the higher the employer's willingness to purchase a house is. The correlation coefficient is 0.718 , whether social security fees are highly related to the willingness to purchase a house, whether social security fees are positively related to the willingness to purchase, and whether The social insurance fees of migrant workers are

Table 5. Kendall correlation coefficient table of willingness to buy a house and monthly income etc.

\begin{tabular}{|c|c|c|}
\hline \multicolumn{3}{|c|}{ Kendall's correlation coefficient } \\
\hline & \multicolumn{2}{|c|}{ Willingness to Purchase } \\
\hline & correlation coefficient & Sig.(Bilateral) \\
\hline Workers' monthly income & $0.531^{\star \star}$ & 0 \\
\hline Employment patterns & $-0.510^{\star *}$ & 0 \\
\hline Social security fee payment & $0.718^{\star \star}$ & 0 \\
\hline Current living conditions & -00.259 & 0.055 \\
\hline Workplace satisfaction & $0.552^{\star *}$ & 0 \\
\hline Working time satisfaction & $0.589^{* *}$ & 0 \\
\hline Labor protection satisfaction & $0.447^{\star *}$ & 0.001 \\
\hline Technical training satisfaction & $0.659^{* *}$ & 0 \\
\hline
\end{tabular}


more willing to purchase houses; the correlation coefficient of the work place is 0.552 ; the work place is moderately related to the willingness to purchase the house; the work place is positively related to the willingness to purchase a house; the higher the work place satisfaction, the higher the willingness to purchase a house; The correlation coefficient is 0.589 , working hours and home purchase We would like to be moderately relevant. The working time is positively related to the willingness to purchase a house. The higher the job satisfaction, the higher the willingness to purchase a house; the correlation coefficient of labor protection is 0.447 , labor protection is moderately related to the willingness to purchase a house, and labor protection is positively related to the willingness to purchase a house. The higher the degree of satisfaction with labor protection, the higher the willingness to purchase a house; the correlation coefficient of technical training is 0.659 . Technical training is moderately correlated with the willingness to purchase a house. Technical training is positively correlated with the willingness to purchase a house. The higher the degree of satisfaction with technical training, the higher the willingness to purchase a house.

With higher monthly income, the ability to purchase a house is relatively high, so the higher the monthly income, the higher the willingness to purchase a house. When the employment pattern of migrant workers is an employer or a boss, their income is relatively high and the ability to purchase a house is relatively high, so their willingness to buy a house is relatively high. The migrant workers who paid social security fees stated that the companies they work in are relatively well-paid. At the same time, farmers who have been paid continuously for five years have the qualification to purchase houses in Guangzhou, so their willingness to buy houses is relatively high. The higher the migrant worker's satisfaction with work, including the work place, working hours, labor protection and technical training, shows that migrant workers are more satisfied with the current work and will have the desire to stay in the city life, so their willingness to buy houses is relatively higher.

4) The Influence of the Characteristics of the Working Site on the Purchase Willingness of the House

From Table 6, Gamma $=1.00$ shows that whether there are relatives and friends in the working area and the willingness to purchase a house are highly relevant. Therefore, when there are relatives and friends in the working area, the likelihood of the migrant worker purchasing a house in Guangzhou is greater; Sig $=0.08$, Explain whether there are relatives and friends in the working area

Table 6. Willingness to purchase-friends and relatives at work cross-tabulation.

\begin{tabular}{lccc}
\hline & & \multicolumn{2}{c}{ Willingness to Purchase (\%) } \\
\cline { 3 - 4 } & & Unwilling & Willing (or purchased) \\
\hline \multirow{2}{*}{ Friends and relatives at work } & No & 100 & 0 \\
& Yes & 77.3 & 22.7 \\
& \multicolumn{3}{c}{ Gamma $=1.00, \mathrm{df}=1, \mathrm{Sig}=0.08$} \\
\hline
\end{tabular}


Table 7. Kendall correlation coefficient table of willingness to buy a house and the cultural environment of the working sites

\begin{tabular}{ccc}
\hline & \multicolumn{2}{c}{ Kendall's correlation coefficient } \\
\hline & \multicolumn{2}{c}{ Willingness to Purchase } \\
\cline { 2 - 3 } & $0.486^{* *}$ & Sig.(Bilateral) \\
\hline cultural environment & $0.481^{* *}$ & 0 \\
Convenient traffic & correlation coefficient & 0 \\
\hline
\end{tabular}

${ }^{* *}$ Confidence (Bilateral) is 0.01 , the correlation is significant. ${ }^{*}$ Confidence (Bilateral) is 0.05 , the correlation is significant.

are significant factors affecting the willingness to purchase a house. Friends and relatives are an important social resource. At the same time, everyone is not an absolute independent individual. Migrant workers who have relatives and friends at the working place can use their social resources and at the same time get emotional satisfaction. Therefore, migrant workers who have no relatives and friends in the working places are more willing to purchase houses in the cities.

As can be seen from Table 7, the significant factors affecting the willingness to purchase a house are the cultural environment of the working area and the convenient transportation of the working area. The correlation coefficient of the cultural environment of the working area is 0.486 . The cultural environment of the working area is moderately related to the willingness to purchase a house. The cultural environment is positively related to the willingness to purchase a house. The higher the degree of satisfaction with the cultural environment of the work site is, the higher the willingness to purchase a house is; the correlation coefficient of the convenience of the work site is 0.481 . The convenience of the work site is moderately related to the willingness to purchase a house. The ease of transportation is positively correlated with the willingness to purchase a house. The higher the convenience of transportation, the higher the willingness to purchase a house.

When migrant workers are highly satisfied with the cultural environment of the work site, they will strive for the next generation to receive a good education in the city, to feel the influence of a good cultural environment, to stay in the city, to integrate into the city life, and their willingness to purchase houses. Relatively high. The migrant workers are more satisfied with the degree of convenience of the work site, indicating that the migrant workers think that the transportation in the city is convenient, and the life travel is more flexible and convenient, and the higher the willingness of the migrant workers to purchase houses in the construction sites.

\section{Analysis Conclusion}

\subsection{Migrant Workers Are Less Willing to Purchase Homes}

The willingness of migrant workers to purchase houses in the working sites, namely Guangzhou, is relatively low, and only $20 \%$ of respondents are willing to 
purchase houses. The social conditions for low purchase intentions are that Guangzhou residents must pay social security fees for foreign resident households for five years in a row. This is a high threshold for migrant workers to buy a house; the low self-condition for migrant workers is migrant workers. The income is generally not high, and the pressure on home buyers is high.

\subsection{Its Own Characteristics Have a Significant Impact on the Willingness of Migrant Workers to Purchase Homes on the Working Sites}

There was a positive correlation between marital status, education level, health status and willingness to purchase a house, and there was a negative correlation between age, personality and willingness to purchase a house. Unmarried people have a relatively high willingness to purchase houses. The higher the degree of education, the higher the willingness to buy a house and the better the health condition is, the higher the willingness to buy a house is. The older the age is, the lower the willingness to buy a house and the willingness of a conservative migrant worker to buy a house is relatively low.

\subsection{Family Characteristics Negatively Influence the Migrant Workers' Willingness to Purchase a House}

When the family's non-labour population is relatively high, it means that the family's burden is heavy, and the willingness to purchase a house in Guangzhou is smaller; when a contracted land is in a hometown, the migrant worker will not give up the contracted land because the peasant has a right to the contracted land. Therefore, the willingness to purchase a house in Guangzhou is relatively small.

\subsection{Employment Characteristics Have a Significant Effect on the Willingness of Migrant Workers to Purchase Homes on the Working Sites}

The monthly income of workers, whether they paid social security fees, job satisfaction (working hours, workplace, labor protection, technical training) and the willingness to purchase a house were positively correlated. The employment pattern was negatively correlated with the willingness to purchase a house. The higher the monthly income, the higher the willingness to purchase a house, and the willingness of migrant workers to pay social security fees is relatively high. The higher the job satisfaction is, the higher the willingness to purchase a house is. The employment form is wage-worked migrant workers, and the willingness to purchase a house is relatively low.

\subsection{The Characteristics of Working Sites Have a Positive and Relevant Influence on the Willingness of Migrant Workers to Purchase Houses}

When there are relatives and friends in the working sites, migrant workers are more willing or willing to stay in the city and integrate into city life. Therefore, 
the willingness of migrant workers to purchase houses in Guangzhou is higher; the migrant workers are more satisfied with the cultural environment and convenience of transportation of the construction sites. The higher the willingness.

\section{Related Suggestions}

\subsection{Provide Guidance for Migrant Workers in Purchasing Homes}

The migrant workers surveyed have relatively weak economic power. Most of them have not paid social insurance in Guangzhou and have little knowledge of real estate transaction information. They have weak resistance to market risks. Therefore, the government or society needs to provide a good intermediary platform. A standardized information service platform. At the same time, the government or the society must help migrant workers control the risk of home purchases, and they can publicize some home purchase guarantees and related support policies. At the same time, they must also incorporate migrant workers into the social security in order to reduce the risk of home purchase indirectly.

\subsection{Improve the Ability of Migrant Workers to Purchase Homes}

The low monthly income of the migrant workers surveyed is a major obstacle to the purchase of houses. Therefore, the monthly income of migrant workers should be increased. The main methods to increase income are: First, subsidies for rural areas adhere to the characteristics. Second, we must appropriately raise the minimum wage for migrant workers. Third, the government provides some migrant workers with the support for the purchase of loans, which can lower the threshold for mortgage loans and reduce the interest burden. This will increase the willingness of migrant workers to purchase houses in the workplace.

\subsection{Increase the Construction of Affordable Housing}

Most of the migrant workers surveyed currently live in rented private houses, and the cost of renting private houses is relatively high. Most of the monthly income of migrant workers pays rent, so the government should expand the coverage of low-cost housing and increase the proportion of affordable housing. Constantly improve the construction of low-rent housing and affordable housing. The price of low-rent housing and affordable housing should be within the spending power of low-income people, the house design should be square, the usage rate should be high, and the status quo of over-optimized prices and unreasonable house design should be improved.

\subsection{Solidify Rural Rights and Interests and Encouraging Migrant Workers to "Bring Funds into the City"}

Most of the migrant workers surveyed have contracted land in their hometowns. In further understanding, they know that migrant workers are reluctant to give up their contracted land in their hometowns. Therefore, even if some migrant workers have already bought houses in Guangzhou, they have not settled in the 
city for a long time, so they must be clear. We should not regard the abandonment of household contracted land as a condition for migrant workers to settle in the city, but let migrant workers take the "asset" into the city with confidence.

\subsection{Improve the Vocational Training System and Strengthen the Employability of Migrant Workers}

The migrant workers surveyed are engaged in labor-intensive enterprises, and their professional and technical capabilities are relatively lacking. Therefore, relevant government departments and enterprises should provide training for migrant workers' professional capabilities. The enterprises provide technical training as the mainstay, and the government provides supplementary education as a supplement. Strengthen the employment capacity of migrant workers.

\section{Future Outlook and Limitations}

This article selects the migrant workers in the Guangzhou working sites as the research object, and conducts exploratory research through questionnaire survey and field research. On the one hand, most of them work in the service industry and factories. The monthly salary is paid for food, clothing, and renting houses. After the transportation and other issues, the rest are already very few; on the other hand, they lack some protections such as welfare guarantees, social insurance, housing provident funds and other related policies. Under the circumstances of household registration restriction, the conditions for home purchase are insufficient. Therefore, it will greatly reduce its desire to purchase, which is the root cause. So, in fact, they hardly belong to this city.

The limitations of this paper are: First, this article is influenced by time and energy. Four sites were chosen as the research sites. The sample representation may not be sufficient for 11 districts in Guangzhou, and it needs to be expanded in the future. Second, the empirical analysis of this article is only descriptive statistics and simple correlation analysis; shortly can be combined with a variety of econometric models and empirical methods for deep-level regression empirical and causes. Third, the policy recommendations can be combined with the specific refinement of local social security policies, and look forward to further development in the future.

\section{References}

[1] Liang, Y. and Zeng, M. (2008) Status Quo Analysis and Countermeasures of Migrant Workers' Housing Problems. Science and Technology Information: Academic Research, No. 1, 43-44.

[2] Song, R. (2011) Status Quo and Safeguard Measures of Migrant Workers' Housing in Ningguo. Modern Agricultural Science and Technology, No. 11, 382.

[3] Wang, R. (2015) Study on the Status Quo and Problems of Migrant Workers' Housing-Take Nanyang City, Henan Province as an Example. Doctoral Dissertation, Huazhong University of Science and Technology, Wuhan.

[4] Gao, B., Li, G. and Chen, Y. (2015) Status Quo of Migrant Workers' Residence and 
Housing Options in the New Urbanization Process-Based on 2013 China Floating Population Dynamic Monitoring Data. Journal of Gansu Institute of Public Administration, No. 6, 81-91.

[5] Liao, J. and Qiu, Y. (2015) Survey on the Status of Migrant Workers' Housing in China. Guangxi Township Construction, No. 7.

[6] Liang, Y., Xie, L. and Li, D. (2017) Analysis and Countermeasures of Urban Housing for Migrant Workers in Liaoning Province. Industry and Technology Forum, 16, 127-130.

[7] Guo, X., Li, X. and Pan, Y. (2015) Research on the Characteristics of Migrant Workers' Housing Needs-An Empirical Analysis Based on the Migrant Workers' Housing Demand Function in the County. Rural Economy, No. 11, 114-118.

[8] Tian, H., Song, X. and Li, S. (2014) Research on Characteristics of New Generation Migrant Workers' Housing Demand and Policy Responses Based on Survey in Chongqing. Northwest Population, No. 3, 79-83.

[9] Hu, Y., Tian, C. and Lai, J. (2017) Research on the Housing Leasing Demand of the New Generation of Rural Migrant Workers in Rural Areas in the West China-Take Chengdu Chenghua District as an Example. China's Collective Economy, No. 16, 122-124.

[10] Tang, R. (2016) Research on Housing Demand and Policy Responses of the New Generation of Migrant Workers in Zhengzhou City. Doctoral Dissertation, Zhengzhou University, Zhengzhou.

[11] Zhu, Z. and Leng, C. (2017) Willingness of Peasant Workers to Buy Houses in Urban Areas and Its Influencing Factors. Finance and Economics, No. 3, 98-109.

[12] Liang, Z., Yang, G. and Guo, J. (2013) Research on the Influencing Factors of Migrant Workers' Willingness to Return to China. Commercial Research, 55, 163-169.

[13] Li, Y. (2016) Survey on the Willingness of Fujian Migrant Workers to Purchase Houses in Cities. Science \& Technology Economics Journal, No. 26, 180-181.

[14] Wang, Y. (2014) Research on the Willingness of Peasant Workers to Purchase Houses in Working Places and Its Influencing Factors. Doctoral Dissertation, Jiangxi Agricultural University, Nanchang.

[15] Cheng, Y., Han, X. and Hu, Y. (2012) Research on Migrant Workers' Willingness to Buy Houses in Cities and Influencing Factors. World Survey, No. 10, 17-22.

[16] Zhang, X. (2012) Research on the Influencing Factors of Migrant Workers' Willingness to Purchase Houses in Construction Sites: A Case Study of Dagang Town, Panyu District, Guangzhou City. Journal of Agriculture and Forestry Economic Management, 11, 1-8. 


\section{Appendix}

\section{Survey Questionnaire on the Willingness of Migrant Workers to Purchase Houses on the Working Site and Its Influencing Factors}

Dear migrant workers:

Hello! I am a student of Jinan University and I am currently conducting a research project. The selection is determined as the willingness of migrant workers to purchase houses at the working site and its influencing factors. Take Guangzhou as an example. I hope this can be used to investigate the rural labor force on the construction site. Buying houses provide advice and provide reference for the government to formulate related home purchase policies. Please answer truthfully. The answer is not correct or wrong. I will keep confidential the relevant personal issues in the questionnaire and promise not to use it as a research institute.

I sincerely thank you for your support and cooperation in my investigation.

1) Are you willing to buy a house in Guangzhou ( )
A. Willing (or already purchased)
B. Unwilling

\section{Own characteristics}

2) Your gender is ( )
A. Male
B. Female

3) Your marital status is( )
A. Married
B. Unmarried

4) Your age is ( )
A. $20 \sim 30$
B. $31 \sim 45$
C. $46 \sim 60$

5) Your education level is ( )
A. Primary school and below
B. Junior high school
C. High School (secondary school)
D. College

6) Which type do you think your character belongs to? ( )
A. Adventure
B. Intermediate
C. Conservative

7) Your health status ( )
A. very bad
B. General
C. Better

\section{Family characteristics}

8) The household non-labor force ratio ((Non-workforce population)/(Total family population)) is ( )
A. $<0.5$
B. $0.5 \sim 1$

9) Is there a contracted land in your hometown? ( )
A. Yes
B. No 


\section{Employment characteristics}

10) Your migrant monthly income is ( )
A. 2000 yuan or less
B. $2001 \sim 4000$ yuan
C. 4001 yuan or more

11) Your employment form is ( )
A. Employer/owner
B. Self-management
C. Wage employment

12) What type of industry is your job? ( )
A. Labor-intensive
B. Capital-intensive
C. Technology-intensive

13) Do you have to pay social security fees ( )
A. No
B. paid but not yet five years
C. Pay and have been in five years

14) Current residence conditions ( )

A. Rental Private

B. Leasing public rental or low-cost housing

C. Work shed or workplace accommodation

D. Others

15) Job Satisfaction ( $1=$ Not satisfied; $2=$ Normal; $3=$ Basic Satisfaction $)$

\begin{tabular}{cccc}
\hline Job Satisfaction & 1 & 2 & 3 \\
\hline Work place & & & \\
Working time & & \\
Labor protection & & \\
Technical Training & & \\
\hline
\end{tabular}

\section{Worksite characteristics}

16) Whether there are relatives and friends in the working site ( )
A. No
B. Yes

17) The cultural environment of the working site ( )
A. Poor
B. General
C. Better

18) Convenience of transportation at the working site ( )
A. Poor
B. General
C. Better 